\title{
Some Critical Reflections About Politically Incorrect Humour at Contemporaneity ${ }^{*}$
}

\author{
Mateus Pranzetti Paul Gruda \\ UNESP_Univ Estadual Paulista, Assis, Brazil
}

\begin{abstract}
Humour discourse and its mechanisms of working has been constantly presented within several instances of quotidian life nowadays (pedagogical methods should be fun, most of the advertising invests in a humorous approach, political manifestations should have good humour involved, amidst many others) and in the last decades the so-called "politically incorrect humour" gained featured and has generated numerous discussions about it, such as: the limits or restrictions that humour should have to follow; what could be considered humorous or not; and the conflicts between that type of humour and the political correctness, which can be comprehend both as a extreme policy of language, thoughts and behaviours or as something necessary to proceed a normalisation on the public sphere. From these questions, I sought to reflect what politically incorrect humour is about and its dialectical possibilities of producing meanings and ability of reinforcing or attacking the current order. Once humour is composed by contradictions (can be at the same time: universal and particular, reactionary and revolutionary, etc.), I present the politically incorrect humour torn between two poles (critical and uncritical) formalising common features and consequences of both possibilities to think critically about how politically incorrect humour can impact into the mode we subjectify and relate with the others and the world.
\end{abstract}

Keywords: humour, discourse, contemporaneity, political incorrectness, political correctness, critical social psychology

\section{Introduction}

Before starting to write specifically about politically incorrect humour at contemporaneity, which is the main topic of this article, it necessary to take a step back and think about general humour in contemporary world. There are a lot of difficulties to analyse current times, but some authors, such as Lipovetsky (2005), Bauman (2000), Jameson (1991), Harvey (1989), among others, point out some characteristics and aspects that can help us to identify and to understand some things related to that. I will highlight two specific ones listed by Lipovetsky (2005): excess and superficiality. It is quite easy to perceive both features acting on social reality nowadays, which can be noticed through some trivial and daily situations. As an example involving those aforementioned characteristics (excess and superficiality), it is common to travelling people to take thousands

\footnotetext{
* Acknowledgements: I have a scholarship from FAPESP (Sao Paulo State Research Foundation, process number: 2011/14832-2) during the doctoral period and, along my research internship at Brunel University London, I had a scholarship provided by CAPES (Brazilian Higher Educational Personnel Improvement Coordination, process number: 99999.005605.2014-02).

Mateus Pranzetti Paul Gruda, Ph.D. student, Post-graduate programme in Psychology, UNESP-Univ Estadual Paulista, Assis, Brazil. Researcher doctoral intern in the Centre for Comedy Studies Research (CCSR) at Brunel University London, Uxbridge, United Kingdom.
} 
of photographs of every single place and thing that she or he is visiting and looking - pay attention here to the excess - but when she or he comes back home, probably those images will not be seen again and if they were these people probably will not even remember of being there, once it was more important to take photos instead of feeling the place - pay attention here to the superficiality.

Relating those features with humour at contemporary world, I agree with Lipovetsky's (2005) idea that we are living in a "humorous society", wherein humour and its mechanisms of working are widespread everywhere, within every single discourse and social practice. If we think about advertising, fashion, social protests, educational methods ("learn should be fun", it's a common phrase/idea that summarises it); among many others, we can realise that all of those fields are invaded by humorous mechanisms of working, such as: parody, irony, sense inversion, mix between sense and nonsense, etc.. But, the most important thing to ask involving that idea of general humour widespread everywhere is what kind of humour is presented within every single discourse and social practice, since this excessive humour is mostly linked to consumerism and light entertainment. In other words, we have predominantly a euphoric and not combative humour within everywhere at contemporary world. Therefore, going beyond this perspective that humour is settled down and has a huge influence on several instances and dimensions of life, everything should be under the aegis of no other humour but the so called "good humour". Connecting both ideas (widespread humour and the overriding requirement of good humour), Billig (2005, p. 13) says that: “... we belong to a society in which fun has become an imperative and humour is seen as a necessary quality for being fully human". Moreover, after the 19th century, to have a good sense humour became an essential personal attribute (Lockyer \& Pickering, 2001).

On times of repelling the frustrations and an extreme hedonism, as described by Bauman (2000) and Lipovetsky (2004), it is possible to have the illusory impression that the simple presence of humorous forms everywhere could provide and help to the materialisation process of that ideal of mandatory happiness at any cost. However, for be connected with that mandatory "good humour" logic, the humour attached and widespread is, as I already wrote above, a facilitator and promoter of consumerism. Besides, that humour is based on light entertainment and depotentiation of criticism and virulence against inequalities and instituted powers. Anyhow those features (criticism and virulence) are not only necessary for the constitution of social via conflicts (Marx \& Engels, 2010), they are also part of humorous discourse along times (Gruda, 2011). Hence, this type of language manifestation is multiple, it can cover dialectically the critical acidity and playfulness harmless, but on this article, among other things, I will highlight how much the critical power of humour has not been stressed, because life at contemporaneity is the time of uninterrupted and compulsory joy.

Within this scenario wherein soft and ludicrous humorous manifestations are predominate, which can smooth any contradictions that could break or question the standard patterns and/or compulsory happiness, it is possible to notice the politically incorrect humour emerging. This "type" of humour a priori would transgress any boundaries imposed by social relations and conventions, provoking discomfort and disputes involving the meanings that it attacks and/or proposes for social body. Through that main mode of operating, politically incorrect humour discourse also acts dialectically, because the transgression can be both essential for criticism and fortify progressive, radically revolutionary and/or counter hegemonic ideas, as well loyal partner of maintenance and reaffirmation of conservative, reactionary and hegemonic order. Therefore, I am proposing a torn inside politically incorrect humour.

On the one hand, politically incorrect humour can be in disagreement of normalisations on public sphere when it occasioning conflicts through the offense and mockery, in its essence it is being consistent with 
instituted and hegemonic order, once the targets of that kind of politically incorrect humour usually are the same social groups and same stereotypes and prejudices that are crystallised for ages in the social body. Instead to promote what is most cost and essential to humour discourse - as Bakthin (1984) thought when he wrote regarding carnivalesque humour on medieval popular parties and on the François Rabelais' work - the ability of transgression and to critic inequalities, power and instituted order. In this way, I call that "politically incorrect humour" as "uncritical", because it is just transgressing boundaries of do not having any limits to its discourse, whilst it is reinforcing what is already placed, rooted, and mummified in current and effective social practices and discourses. Summarising: "uncritical politically incorrect humour" is transgressive for reinforcing established and dominant order. And two key arguments for its defence are: (1) purported unlimited freedom of expression; and (2) the phrase "jokes are only jokes" (Gruda, 2013).

While, as a counterpoint to this "uncritical politically incorrect humour", there is the "critical politically incorrect humour" which is revolutionary and libertarian indeed, since it aims to mock the status quo, authority and power figures, most of time causing the possibility of that takes place deep reflections about world and human relations. Hence, "critical politically incorrect humour" is "politically incorrect" for affronting the standards actions and thoughts that are agreed as corrects and that should be followed, and of course those are liked with the hegemonic way of living — which is founded on economical inequalities and leak of rights - it is "critical" for attacking and making explicit what sustain dominant order, which can make possible reflections and, perhaps, real changes on actions, ideas and, why not, the order itself.

To sum up, on one hand, humour serves and intends to rethink and to question instituted; on other hand, it reinforces prejudices and hegemonic/dominant order. This dialectical dichotomisation points out what are the boundaries to characterise it into one or into other way. Of course, all of this is somehow contradictory and it is not problematic, since humour is full of contradictions, which according to Billig (2005) are increased for three principal paradoxes related to humour: (1) Humour is universal and particular, because is presented within any society, however people do not laugh at the exactly same things; (2) Humour is social and antisocial, once it can be gregarious when it joins people through shared fun, nevertheless it also excludes determined social groups when it repeatedly mocks about them; and (3) Humour is analysable and resistant to be analysed, since a lot of thinkers from different fields made and make analytical considerations about it and, concomitantly, when humour is being analysed it can stop being funny or stop making sense as humorous. Therefore, highlighting a general dialectical feature of humour, at the same time that needs to transgress an established and known order to occur (Alberti, 1999; Bergson, 1980; Geier, 2011; Palmer, 1994; Propp, 1982), humour also should respect some imposed limits to the maintenance of sociability (Berger, 1999; Billig, 2005; Critchley, 2002).

Thus, proceeding with a dialectical reading, according to opposite processes and dimensions are understood as complementary to each other, unlike as antagonise poles that exclude each other (Oliveira, 2005; Marx, 2010), "politically incorrect" discourse exists concomitantly of "politically correct" discourse. In a similar way, the latter also has distinct perspectives within it, which are linked with different purposes that influence how politically correct discourse is constituted, moulded and spread. For that reason, that discourse can be comprehended going beyond one single and exclusive meaning. Anyhow, it is possible to notice that political correctness has been used indiscriminately in last decades, which promotes more the crystallisation of a unique meaning for it, to be known, that political correctness is just a mode of coerce freedom of thought, action and language. That's why the expression "political correctness" is commonly used as negative label, but, instead, as I affirmed some lines ago, is feasible to read politically correct discourse following other perspectives. 
Finally, to outline the parts of this text, it contains: (1) a few words about my theoretical perspective within Psychology; (2) a brief contextualisation of political correctness; (3) a huge description about both categories of politically incorrect humour that I am presenting here, which are critical and uncritical, reflecting about their features and consequences for the subjects and the social relations; (4) then, I unpack some examples of both categories; and finally (5) there is my final reflections and considerations.

\section{Critical Social Psychology}

On this part, I stress really briefly the theoretical perspective within Psychology that I am inserted into and why it is connected with the article's topic.

The principal theoretical reference of mine here is Critical Social Psychology, which arose as a consequence of the so-called "crisis" of Social Psychology during 1960s and 1970s decades (Ibáñez, 1990; Parker, 1989) and is usually labelled only as Critical Psychology. It is mainly featured, according to Parker \& Shotter (1990), for the idea that all knowledge is constructed and for its interesting of analyse and study discourses, which Parker $(2015$, p. 3) indicates that: “... marks a conceptual break from behavioural and cognitive models of language as expressions of response to stimuli or as communication of ideas from inside the head of an individual to others". Moreover, following Parker's ideas, discourse is understood as "critical discursive practice" what is important for psychologists associated with Critical Psychology, since "... it enables us to turn around and treat our own discipline as a collection of texts susceptible to deconstruction" (Parker, 2015, p. 6).

At the same time, discourses are not comprehend as mere information transmitter neither just a format of speaking about something, discourses are concomitantly product and producers (Pêcheux, 1997; Orlandi, 1999), in other words, those are related to social and historical conditions and realities, but also influence the construction of these. Therefore, humour discourse is understood going beyond a shape of language, it is produced by social and historical conditions, as well produces consequences and impacts on subjects and social reality (Parker, 2015).

\section{Discussion}

To write down in a few words about the history of the term and consequently ideas related to politically incorrect humour, it emerged in contraposition of political correctness, which, according to Cameron (1995), Dunant (1994), Hugues (2009), Williams (1995), Wilson (1995), among others, date back to the 1960s. One of main ideas related to political correctness is promoting normalisations on public sphere, defending multiculturalism and so-called minorities. Nevertheless, along decades, the perspective that political correctness is only deleterious, promoted by minorities and aiming to promote imprisonments of thought and language, either as an inverse form of oppression to dominant, gained force-Wilson (1995) names it as "political correctness myth", which was woven and successfully spread by conservatives through media and, afterwards, was rotted in common and popular sense - though, this predominant reading related to political correctness was ideologically linked with dominant ideologies, thereby to question the domination and the mechanisms of domination propagated through social and discursive practices is imputed as a policing of conducts and a process of interfering on private freedoms, whilst any servile behaviours of maintaining and reproducing dominant order are completely acceptable and not view as politically correct in a negative sense.

However, as dialectical perspective guides my way of thinking as I already stated, I highlight that political correctness is not only about those things, indeed there is such idea of policing of conducts (acts) and utterances 
(language), but I diverge of that current idea of connecting political correctness with "minorities dictatorship", for me the policing of conducts, thoughts and utterances is related to ideals of light world and life (Rojas, 2007) and to the dessubjetivisation processes (Lipovetsky, 2004; 2005), which points out that there is no other way to live out of capitalism-occidental-liberal ideals and dogmas.

Anyhow, independently of what perspective related to political correctness is talked about, one thing is quite accurate about this: political correctness raises and defends limits indeed, still the necessary questions regarding the limits are: what are the limits? And to whom are serving those? Furthermore, any discourses that violate those limitations - whatever these are and to whom are serving — can be labelled as politically incorrect and those questions can also be used as key questions to guide us thinking about which politically incorrect humour (critical or uncritical) we are dealing with.

\section{Critical Politically Incorrect Humour}

In the case of "critical politically incorrect humour", it is "humour" because is based on mechanisms that make a discourse works as humorous (such as: inversions; wordplays; irony, satire; mix between sense and nonsense; among others). It is "politically incorrect" since it affronts patterns of thought and conduct agreed as the correct ones and that should be followed, which are associated with the hegemonic mode of existence- - that is found on economical inequalities and lack of rights. At least, it is "critical" because attacks and makes explicit what is supporting dominant and current order, which can enable deep reflections about reality and consequently promote changing attitudes and ideas.

Even if according to Critchley (2002) and other authors - such as excerpts from Berger's (1999) and Minois' (2003) works - humour is usually and broadly reactionary, since it reinforce the social conventions, the first quoted author also states that humour is dialectical, therefore cannot be just reactionary, it also can be revolutionary. To explain this division, Critchley (2002) proposes two categories within humour: true humour and untruth humour. The first one is against current order and helps us to think other possibilities, whilst latter is reactionary and partner of maintenance current and unequal order when it openly and aggressively defends it.

Approximating my "critical politically incorrect humour" category with the Critchley's true humour, both have the characteristic of ".. to do more than release tension, it has to 'liberate' the will and the desire, it has to 'change the situation"” (Griffiths, 1976, p. 20, as cited in Critchley, 2002, p. 10). In other words, those types of humour (critical and true) are not mere entertainment; fun for the spirit or a mode of temporarily eliminates the tensions caused by lived reality. Instead, true humour and "critical politically incorrect humour" have the commitment of promote discussions about the basis that lived reality is founded on putting in perspective, which implies on questioning and turn view for other possibilities to what is asserted as immutable truths, which are crystallised and mummified through social body and settled in the collective subjectivity.

Moreover, both types of humour (true and critical politically incorrect) promote to realise that the things of the world are fool, when they take off the serious cover of those showing uncountable incongruence and contradictions within them. However, as stated by Critchley (2002, pp. 17-18): "by showing us the folly of the world, humour does not 'save' us from that folly... but calls on us to face the folly of the world and change the situation in which we find ourselves". Hence, "critical politically incorrect humour" and true humour do not only mock and relativise the seriousness of everything; they have changing of reality as the main aim.

Unpacking the Critchley ideas a little more, he points out that humour can have a ludicrous character when it demonstrates the fragility and fallibility of social structures, which are comprehend as immutable or fully 
provided of certain, even if are liable to be eroded by something apparently inoffensive: humorous jest. This is quite similar of that tale wherein invisible clothes let the emperor naked. The king not only shows himself stripped of his clothes, but also stripped of his alleged reason and intelligence, once he is fooled and seduced by the mocking tailor and did not realise that he was not wearing anything and the marvellous clothes does not even exist.

Another division in two types of humour that is close of mine is that one proceeded by Billig (2005), who distinguishes the disciplinary humour of rebellious humour. For this author, both kinds can be considered expressive forms of ridiculous and to briefly describe those categories, they are featured as it follows: disciplinary humour mocks who are deviants or are against social norms; serving for the maintenance of instituted order; whilst rebellious humour mocks social norms that structure unequal reality, which can allow this type of humour to be understood as a discourse committed with change and contest of that quoted rules. Consequently, latter is revolutionary/radical and the first one is conservative/reactionary. Using Billig's words: "disciplinary humour contains an intrinsic conservatism, while rebellious humour seems to on the side of radicalism" (2005, p. 2002).

When I am characterising "critical politically incorrect humour" as means of expressing a combative and questioning worldview, it is possible to reach to a dilemma: "but is not any type of humour based on breaking usual logic?", the answer for this question would be that every humour is founded on breaking usual logic indeed; nevertheless it is not always related with taking to a counter hegemonic, alternative or revolutionary perspective. However, plasticity is a leading feature of humour, therefore those adjectives (counter hegemonic, alternative, revolutionary) can relate to different things into different social-historically contexts.

To rupture instituted is something in constant movement, hence critical humorous manifestations are not feasible of being prisoners or eternal permanence — unless while inequalities that is against for still lasts. It is relevant to stress I am not discussing about crystallised positions within locus of power, but about ideas and ideals that are widespread and shaping the societies, through ideological forms (Chauí, 1994) and because of hegemony (Gramsci, 1976). Therefore, humour is free to mock about those occupying power positions, but if those are trying to promote radical changes in the way of how the existence is and because of that things specifically are aim of jest, this will be a reactionary, uncritical, and cynical humour.

In other words, critical humour is the place of opposition, affirmation that remind me the phrases: "there is no favourable humour" from Ziraldo Pinto (1973), a well-known Brazilian cartoonist, and "favourable humour is not humour, it is advertising" from Millôr Fernandes, another Brazilian humorist. From these, it is not mandatory for humour to be associated with militancy in favour of "lost causes" (Žižek, 2008) to be considered as critical, albeit to be affiliate to those ones show its critical essence. Nevertheless, when it is used to combat any contrary ideas against the unequal order, or to stigmatise even more the oppressed, humorous discourse can be comprehended as far away of any critical perspective. Because of that, according to Critchley (2002, p. 11), is possible to attest: “... the great importance that humour has played in social movements that have set out to criticize the established order, such as radical feminist humour: 'how many men does it take to tile a bathroom?', 'I don't know', 'it depends how thinly you slice them'”.

Critical humour is also similar with Hart's (2008) proposition of humour as "weapon of the weak". While, correlating the idea of "state of exception" formulated in a genealogical way by Agamben (2004) with the inverted idea that uncritical humour (and specifically in the case of "uncritical politically incorrect humour", as I am proposing within this article) is oppressed nowadays, otherwise of being understood as important weapon 
for the discourses of the oppressors. The same perspective is outlined in analogous way by Billig (2005, p. 203), since according to him: "those who make racist or sexist jokes often claim to be rebelling against the demands of 'political correctness', placing themselves on the naughty, contestive, powerless side". Tactic that relies on the maximum that power is always on the opposite side, then the minorities are censuring any discourse and imposing a dictatorship to the thought, not the humorists linked with uncritical politically incorrect humour, which are always reinforcing the hegemonic and dominant discourses and order, "thus even the powerful can justify their humour on the grounds that it is challenging, not exercising, power" (Billig, 2005, p. 204).

Because of the constant movement between dialectical features possible for humour (particular/universal, gregarious/exclusionary, critical/uncritical), even a critical humour against dominant order can have opposite effects and, otherwise provoking cracks on this order, it can strengthen that. To describe this process, I refer to Žižek's (2002, p. 71) parody of the "Homo Sacer" of Giorgio Agamben, which wrote that: “... the predominant liberal mode of subjectivity today is "Homo sucker" "who "... tries to manipulate others, ends up being the ultimate sucker sucker himself. (Therefore), when we think we are making fun of the ruling ideology, we are merely strengthening its hold over us". Capital, using the hands and arms of entertainment industry, is extremely skilful in neutralising critical humour, making it as a Žižek's "Homo sucker" discourse when capital encompasses criticism into its mass media. That action does not need to use censorship techniques to criticism; the mere fact of turning it to another commodity victim of fetishism is enough for softening (or even destroying) the critical content, or proceed to a creation of a niche market of critical cultural products against current and dominant order.

\section{Uncritical Politically Incorrect Humour}

Politically incorrect humour is characterised for breaking settled limits, however if this humour would be transgressive without any reflection or self-criticism, it will be able to be labelled as an "uncritical politically incorrect humour". The violation of limits referred is related to topics, matters and themes that are comprehend as offensive for some social segments, therefore those are related to the whole social body, in other words, it is necessary to take some care to deal with those topics. Remembering that offensive character of things is transitory and construct through distinct social and historical contexts as well.

The "uncritical politically incorrect humour" is basically a mode of reinforcing prejudices and social violence in an aggressive and cynically way. The principal arguments to defend this kind of humour are: the phrase/idea "jokes are only jokes"; and a purported unlimited freedom of expression (Gruda, 2013). In this section I will unpack these both points, starting with the phrase/idea that "jokes are only jokes".

Possenti (2005) writes that jokes occurs because of the social and historical conditions wherein are being produced, which reflect the conflicts; prejudices; accepted and rejected values at each historical time; stereotypes, etc.. Moreover, that author states that jokes work with a " ... prohibited, underground, unofficial discourse..." (Possenti, 2005, p. 25, translated from Portuguese) regarding varied themes, but especially regarding taboos topics. According to Lockyer (2010, p. 134), the argument "this is a only a joke" "... can be used as a rhetorical strategy to curtain serious critical debate about the political implications of, and ethical limits to comedy", which implies that: "this rhetorical strategy becomes particularly significant politically if it is used as a defence for the repeated and routine mocking of specific class groups" (Lockyer, 2010, p. 134). Following Lockyer's ideas related to this point that jokes are purported to be harmless; it is a rhetorical device for justifying reinforce prejudices settled since a long time ago into social body, I can think with the last quoted 
author that is a strategy for impeding any type of discussion or questioning about what is humorous affirmed through jokes. It is like that this phrase "jokes are only jokes" could purified all content or intention expressed, once it is "only" humour. In other words, it should not be taken in a serious way. Instead of it, according to Lockyer (2010), this perspective ignores the ethical limits and political and social implications that even humour discourse has and should observe.

As stated by Weaver (2011b), "jokes are only jokes" is connected with the idea that humorous manifestations are harmless and, consequently, cannot be cause any damage and nobody should be offend by a humorous enunciation, which this author characterise as a "exculpatory approach". Hence, Weaver (2011a, p. 414) stresses in another of his works: “... humour is not always benign, nor does it always work for the social good, and, although claims of offensiveness differ, humour can, in particular readings, serve ideological functions for serious discourse". This is interesting to demonstrate that the argument used to defend "uncritical politically incorrect humour" that it is offensive and can break any social limit, but at the same time is harmless in a social point of view, is a fallacious reason. After all, "uncritical politically incorrect humour" deals with serious and real questions/topics/matters, even if it uses humorous mechanisms, which does not impede it to serve ideologically to really serious discourses.

Finally, Billig sums up the controversy between the statements that prejudicial jokes are or are not only jokes. This author writes that: “... defenders will typically claim that the joke is 'just a joke' whereas accusers will contend that a racist joke can never be 'just a joke' (e.g., Jaret, 1999)" (Billig, 2005, p. 165), exemplifying that while "Christie Davis (1990) defends ethnic jokes on the grounds that such jokes are generally harmless because the jokers do not believe in stereotypes that jokes employ" (Billig, 2005, p. 165), the critics of that perspective affirm that "... ethnic jokes recycle stereotypes and that anyone laughing at such jokes is validating prejudiced images, regardless of the claims to be 'just joking' (Boskin, 1987; Husband, 1988)" (Billig, 2005, p. 165).

Unpacking both affirmations from Billig's quotes, it is hard to defend that thinking line of lack of responsibility from the part of humorists who tell prejudicial jokes, once they would not believe in the reinforced stereotypes within their humorous manifestations. Even if were possible to trust in some ignorance of the humorists, which would demonstrate complete separation from the social-historical reality wherein he/she is living, this does not mitigate or eliminate the prejudicial content spread by them. This seems to that infant idea that if I close my eyes for something, it will not exist anymore. Nevertheless, even if someone does not have confidence in the prejudices spread through jokes, the context wherein those are enunciated will make they work as prejudicial jokes and reinforce the stereotypes that are based on-as the example of the expression "black period of history" analysed by Possenti (1995) in what, independently of the speaker intentions, can be understood as racist under the Brazilian social-historical context.

Therefore, if the humorist does not believe in those stereotypes that are foundations to prejudicial jokes, he/she should mock about stereotyping processes that reinforce prejudices, because, when they uncritically reproduce those, they are only repeating the discourses and consequent order that they pretend to deny the existence or effectiveness.

Now I pass to comment the other key argument used to defend "uncritical politically incorrect humour": a purported unlimited freedom of expression. As stated within "The Universal Declaration of Human Rights"- highlighting that this cannot be understood as completely universal and global, for a critical analysis related to that, see: Santos (1997) and Žižek (2005)—proclaimed in the General Assembly of United Nations 
(NU) on December of 1948, the idea of freedom of expression is presented in the Article 19 as it follows: "Everyone has the right to freedom of opinion and expression; this right includes freedom to hold opinions without interference and to seek, receive and impart information and ideas through any media and regardless of frontiers" (NU, n.d.). However, the freedom of expressing ourselves is not something unlimited as it is possible to realise from the second paragraph of Article 29: "In the exercise of his rights and freedoms, everyone shall be subject only to such limitations as are determined by law solely for the purpose of securing due recognition and respect for the rights and freedoms of others..." (NU, n.d.). In other words, the respect for the others is embedded into the own exercise of expressing ourselves. What in some way does not cancel the possibility of conflicts from discordances between different points of view, even because expression is also conditioned for the historical and social clashes that are crystallised within discourses (Maingueneau, 1997).

The main problem involving "uncritical politically incorrect humour" and that aforementioned question is its unilateral understanding of discourse construction, because when it ignores that discourses are product of social relations (Orlandi, 1999; Pêcheux, 1997), it does the same to the possibility of contradiction against its humorous manifestations. Therefore, distinctly from what is expected by humorists linked with "uncritical politically incorrect humour" and similar with the Newton's Third Law, wherein every action correspond a reaction in the contrary way, prejudicial or racist jokes will have answers and protests by social movements that feel offended by. And that counter-offensive should not be necessary characterised as censorship. Instead of this, the questioning are relevant when remember that humour only based on prejudices, stereotypes and gratuitous and aggressive offenses does not help to criticise inequalities, otherwise it collaborates with widespread and reaffirm those.

Moreover, the cynical reason of contemporaneity (Safatle, 2008; Žižek, 1994; Sloterdijk, 2012) acts in radical mode within the "uncritical politically incorrect humour" discourse, once the deleterious prejudices for an idea of a more egalitarian society are not just spoken without any embarrassment by the humorists associated with that kind of humour, those are widely justified by the two key arguments aforementioned and by the contemporary cynicism that mocks and nullify the conflicts between contradictions, when it legitimises both positions (Safatle, 2008; Silva \& Beer, 2011) through a process of a "general ironisation of conducts" (Safatle, 2008), which does not deny the acceptability of positions and concomitant contradictory values.

\section{Some Concrete Examples of Politically Incorrect Humour}

Trying to materialise those categories of politically incorrect humour discussed, I will present some examples of both things. A classic one to explain some differences between uncritical and critical politically incorrect humour is the racist joke. The most common thing in a racist joke is demonstrating that a specific ethnic group is inferior to others ethnic groups (Weaver, 2011b), but if one society considers racist jokes something impolite and inappropriate to be told in public, comedians that insist on telling this type of joke could be labelled as politically incorrect humorists. However, in my perspective this politically incorrect humour is uncritical, because it is not reflecting about reinforcing those ideas that are against respectfully living together. Therefore, the transgression promoted for "uncritical politically incorrect humour" is following the way of maintaining the unequal foundations of social reality, not to question these.

On the other hand, if the target of the racist joke is racism or racists, this could be comprehended as a "critical politically incorrect humour" manifestation. It will be politically incorrect because the topic is still a delicate one, the difference will be in how it is approached. A good example of it is one performance from 
Aamer Rahman, an Australian stand-up comedian, called "reverse racism". During this performance, Aamer says that he agrees with existence of reverse racism, if basically the history of world were inverted, in other words, if black, Asian and Latin American people has colonised the world, oppressed and make white as sleeves, so white people would be discriminated otherwise black, Asian and Latin Americans. His conclusion is: if after hundreds of years of that (other ethnics groups oppressing white people), he get on a stage and makes fun about white people, it will be reverse racism. Here one aspect of dominant order-unequal form of treating people because his/her ethnic background - is targeted of criticism via mockery with an ironically inversion in how history was. Hence, the transgression proceeded was located on critical deconstruction of something naturalised by conservative and reactionary discourses (racism and ideas that some ethnics are inferior), which are linked with and sustain hegemonic and dominant order.

In Brazil, for example, there are people who say that racism does not exist anymore here, but, for examples, most of arrested people in my country are black, the number of black students at Brazilian public universities is really small, in other words, though some things in Brazil are happily changing related to some affirmative action by which is tried to repair some historical debts with excluded and oppressed ones; Brazil still have a dominant sense and order based on racism.

\section{Final Considerations}

To finalise the article, I would like to stress again what I consider the main ideas exposed before:

(1) Humorous aspects and mechanisms of working (parody, irony, inversion of sense, mix between sense and nonsense, among others) are widespread everywhere at contemporary world, but that extensive humour is basically connected to promoting entertainment and fun, besides to be partner of a mandatory and exacerbated consumerism;

(2) Politically incorrect humour origins against political correctness, but once this is not composed by a unique perspective, it is about promoting normalisations on public sphere via discussing and protecting multiculturalism and "minorities", political incorrectness will be diverse too;

(3) Humour is dialectical, which implies that we cannot say that humour is just like this or just like that; in other words, humour is like this and like that at the same time; relating that idea to my topic, that is the reason why politically incorrect humour should not be understand only as transgressive discourse, since sometimes it will be transgressing boundaries and limits for reinforcing statements from dominant order ("uncritical politically incorrect humour"). But in association with dialectical principle, sometimes politically incorrect humour can be transgressive when it is ironic and attacks those dominant ideas and statements promoting critical thinking and reflections about reality ("critical politically incorrect humour").

\section{References}

Agamben, G. (2004). Estado de exceção: Homo Sacer II. São Paulo: Boitempo Editorial.

Alberti, V. (1999). O riso e o risivel: na história do pensamento. Rio de Janeiro: Zahar.

Bakthin, M. (1984). Rabelais and his world. Bloomington: Indiana University Press.

Bauman, Z. (2000). Liquid modernity. Massachusetts: Polity.

Berger, P. (1999). Risa redentora: la dimensión cómica de la experiencia humana. Barcelona: Kairós.

Bergson, H. (1980). O riso: ensaio sobre a significação do cômico. Rio de Janeiro: Zahar.

Billig, M. (2005). Laughter and ridicule: Towards a social critique of humour. London: SAGE Publications.

${ }^{1}$ Retrieved from https://www.youtube.com/watch?v=dw_mRaIHb-M 
Cameron, D. (1995). Verbal hygiene. London: Routledge.

Chauí, M. S. (1994). O que é ideologia?. São Paulo: Brasiliense.

Critchley, S. (2002). On humour. London: Routledge.

Dunant, S. ed. (1994). The war of the words: The political correctness debate. London: Virago.

Geier, M. (2011). Do que riem as pessoas inteligentes?: Uma pequena filosofia do humor. Rio de Janeiro: Record.

Gramsci, A. (1976). Escritos politicos. Lisboa: Seara Nova.

Gruda, M. P. P. (2011). The politically incorrect humour and the backbiting discourse in South Park (Master's thesis). Retrieved from Repositório Institucional da UNESP (http://hdl.handle.net/11449/97548).

Gruda, M. P. P. (2013). Questionando alguns argumentos-base que sustentam um tipo de discurso humorístico politicamente incorreto (eletronic version). Zero Degree, 1(1), 219-233. (in Portuguese)

Hart, M. (2008). Humour and social protest: An introduction. In M. Hart, \& D. Bos (Eds.), Humour and social protest (pp. 1-20). Cambridge: Cambridge University Press.

Harvey, D. (1989). The condition of postmodernity: An enquiry into the origins of cultural change. Oxford: Blackwell.

Hughes, G. (2009). Political correctness: A history of semantic and culture. Hoboken: Wiley-Blackwell.

Ibáñez, T. (1990). Aproximaciones a la psicología social. Barcelona: Sendai.

Jameson, F. (1991). Postmodernism, or, the cultural logic of late capitalism. Durham: Duke University Press.

Lipovetsky, G. (2004). Os tempos hipermodernos. São Paulo: Barcarolla.

Lipovetsky, G. (2005). Era do vazio. Barueri: Manole.

Lockyer, S. (2010). Chavs and Chavs-not: Social class in little Britain. In S. Lockyer (Ed.), Reading Little Britain: Comedy matters on contemporary television. London: I.B. Taurus, 95-110.

Lockyer, S., \& Pickering, M. (2001). Dear shit-shovellers: Humour, censure and the discourse of complaint. Discourse Society, 12(5), 633-651.

Maingueneau, D. (1997). Novas tendências em Análise do Discurso. Campinas: Pontes.

Marx, K. (2010). Manuscritos econômicos-filosóficos. São Paulo: Boitempo Editorial.

Marx, K., \& Engels, F. (2010). Manifesto of the communist party. Marxist Internet Archive. Retrieved from https://www.marxists.org/archive/marx/works/download/pdf/Manifesto.pdf

Minois, G. (2003). História do riso e do escárnio. São Paulo: UNESP Press.

Nation United. (n.d.) The Universal Declaration of Human Rights. Retrieved from http://www.un.org/en/documents/udhr/index.shtml.

Oliveira, B. (2005). A dialética do singular-particular-universal. In A. A. Abrantes, N. R. Silva, \& T. F. Martins (Eds.), Método histórico-social na psicologia social (pp. 25-50). Petropólis: Vozes.

Orlandi, E. (1999). Análise de discurso-Princípios \& procedimentos. Campinas: Pontes.

Palmer, J. (1994). Taking humour seriously. London: Routledge.

Parker, I. (1989). The crisis in modern social psychology: And how to end it. London: Routledge.

Parker, I. (2015). Psychology after discourse analysis: Concepts, methods, critique. Sussex: Routledge.

Parker, I., \& Shotter, J. ed. (1990). Deconstructing social psychology. London: Routledge.

Pêcheux, M. (1997). Semântica e discurso: uma crítica à afirmação do óbvio. Campinas: UNICAMP Press.

Pinto, Z. A. (1970). Ninguém entende de humor. Revista Vozes de Cultura, 64(3), 21-37.

Possenti, S. (1995). Politically incorrect language and discourse analysis (electronic version). Journal of Language Studies, 3(2), 125-142. (in Portuguese)

Possenti, S. (2005). Os humores da língua: Análises lingüisticas de piadas. Campinas: Mercado de Letras.

Propp, V. (1982). Comicidade e Riso. São Paulo: Editora Ática.

Rojas, E. (2007). El hombre light: una vida sin valores. Madri: Temas de Hoy.

Safatle, V. (2008). Cinismo e a falência da crítica. São Paulo: Boitempo Editorial.

Santos, B. S. (1997). A multicultural conception of human rights (electronic version). Critical Journey of Social Sciences, 48, July, 11-32. (in Portuguese)

Silva, P. J. C., \& Beer, P. A. C. (2011). About cynicism in a time of ironical identifications (electronic version). Trivum, 1(3), 84-98. (in Portuguese)

Sloterdijk, P. (2012). Crítica da razão cínica. São Paulo: Estação Liberdade.

Weaver, S. (2011a). Jokes, rhetoric and embodied racism: A rhetorical discourse analysis of the logic of racist jokes on the internet. Ethnicities, 11(4), 413-435. 
Weaver, S. (2011b). The rhetoric of racist humour: US, UK and global race joking. Ashgate Publishing.

Williams, J. ed. (1995). PC wars: Politics and theory in the academy. London: Routledge.

Wilson, J. K. (1995). The myth of political correctness: The conservative attack on higher education. Durham: Duke University Press.

Žižek, S. (1994). Mapping ideology. London: Verso Books.

Žižek, S. (2002). Welcome to desert of the real!: Five essays on September 11 and related dates. London: Verso Books.

Žižek, S. (2005). Against Human Rights. New Left Review, 34, July-August, 115-131.

Žižek, S. (2008). In defense of lost causes. London: Verso Books. 